\title{
Mind expeditions
}

Fighting the good fight.

\section{Brenda Cooper}

The bright light shining on the podium made it impossible to see the myriad student faces out there, but I knew what they would look like. Earnest. Curious. Unblooded. They'd be in jeans, with glasses that let them go far away if I bored them, and writing on the insides of their arms to stare at and study for their next class.

A blonde woman with wisps of flyaway hair and a linen suit coat over linen shorts over black boots introduced me. "Please welcome Private First-Class Eleanor Practice to career day. She'll tell you about her first job in Continental Security."

That was my opening. "People used to join the forces to see the world."

Soft laughs floated up from behind the screening, blinding light.

"But I've never been out of San Diego. Thank you for inviting me. After my talk, some of you may want to join us, some may decide you don't like the idea after all.

"The - event - happened on our first virtual mission. I thought it would feel like a video game. The team was me, Alvar from Mexicali and Louisa from Toronto. We came from three countries and never met in person."

I knew what they looked like well enough that I'd recognize them on the street. But I did not know how they felt or smelled or walked. They might not recognize me.

"We were in the Yucatan, trying to stop a drug ring, help Mexico rebuild. Our weapons were databases and wireless mesh, data blockers and listeners.

"An agent on the ground had thrown a hidden mesh net over a small valley. We used it to watch a poor family's house. Palm roof, pressboard walls." I swallowed, seeing it again. So poor. "The father and the two boys carried drugs for the valley kingpin, the mother cooked tortillas and fish soup. There was a little girl in a wheelchair. Maribel. She was the reason for the drug running. Money for Maribel's treatment."

I had hated the assignment then.

"Louisa and Alvar and I talked while we watched, tried to say tough things so we wouldn't get sentimental. We wanted to stop the bosses.

"We were gathering evidence. It wasn't for us to act. We had no bodies there. International law kept us from listening inside, of course, but Mexico is a hot place and many conversations happen outside."

The audience was very quiet. I hoped they were listening. In the wings, soft light fell on the blonde's face. She watched.

"We expected Americans and arrests. The men who came were Mexican. We recognized at least one of them as a drug runner. They hung in the shadows, moved like black shadows, like the devil." I shouldn't say such things. "Like special operations. Trained. They slid against the house, planted charges near the doors and windows and then stood on a hill under a tree, watching and smoking and laughing.

"It began to rain. I hoped the explosives would grow too wet. It was my job to put the father in jail; not to see him murdered. He loved his daughter.

"When he opened the door, the house bloomed with fire.

"He fell right there, his face black and his clothes charred and smoking.

"The older boy ran out. The mother followed, carrying a small figure, and screaming

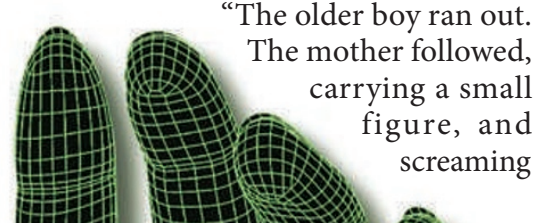
paraplegic, wanted to leave her there and let it be over for her."

There was a tear on my cheek. I hoped the auditorium lights weren't picking it up.

"But Louisa whispered in my ear and Alvar said, 'I’ve called help.'

"I had a team. Maybe someday Maribel would have a team. The doorway smoldered and we had to pass her parents' bodies. Her mother had cleared the space for her before she died. We'd have to be fast and precise. I sent signals to her chair. Forward and back. Testing. When I knew I could do it, I lied to the chair and told it to expect a hill and go fast and hard.

"The chair burst through, raced too fast down the ramp, teetered, didn't fall. The signal was better now, so I guided it a few more yards and left her in shade to wait for help."

I paused and waited, then spoke softly. "Maribel is alive and in school. Her parents' employers are in jail."

I waited for the audience to react. A clap, then another, then another.

I rolled my chair to the front of the room to take questions.

Brenda Cooper lives in Seattle where she is a technology professional, a futurist and a science-fiction writer. Watch for her next novel, Mayan December, from Prime Books in 2011. Learn more at www. brenda-cooper.com. 